\title{
Old English verbs of learning: Information and knowledge acquisition $^{1}$
}

\author{
Miguel Lacalle Palacios \\ University of La Rioja
}

The aim of this article is to provide an inventory of Old English verbs belonging to the class of learning on the grounds of their common semantic components and shared grammatical behavior. The framework of verb classes and alternations and Role and Reference Grammar provide the theoretical basis for this study. Both textual and lexicographical sources have been used to select the data for the analysis of the linking between semantics and syntax with these verbs. The main conclusion of the article is that, considering the constructions and alternations in which they are found in Old English, the verbs (ge)frignan, (ge)leornian, ofäcsian, and onfindan are the best candidates for membership of the class of verbs of learning.

Keywords: alternations; constructions; Old English; verbs of learning

\section{Introduction}

This article is intended to contribute to the study of the semantics and syntax of Old English. More specifically, it focuses on verbs of learning, which are defined in the present work as verbs that belong to states of affairs comprising a Cognizer who learns some Content, as in Steve learned how to cook an omelet; or an Effector that causes a Cognizer to get to know some Content, as in Steve learned how to cook an omelet thanks to the chef's teachings. The article addresses the question of the class membership of verbs of learning by assessing its consistency as to meaning components and grammatical behavior. The line is

\footnotetext{
${ }^{1}$ This research has been funded through the grant FFI2017-83360P, which is gratefully acknowledged.
}

Miguel Lacalle Palacios, Selim26 (2021): 25-56.

ISSN 1132-631X / ISSN-L 2792-3878 / https://doi.org/10.17811/selim.26.2021.25-56 
taken that for verbs to belong to a certain class they must convey similar meaning components (described by means of Aktionsart types and thematic roles) and show similar grammatical behavior (understood as the morphosyntactic realization of arguments). In other words, the inventory of Old English verbs of learning must not be based on notional definitions of meaning but rather on semantically motivated grammatical convergences. This avenue of research, therefore, contributes to a synchronic organization of the Old English lexicon that takes the syntactic range of verbs into account.

The article is structured as follows. The previous studies in the verbal classes of Old English are reviewed in Section 2. Then, Section 3 presents the theoretical basis of the research, which draws on the framework of verbal classes and alternations as well as on Role and Reference Grammar (henceforth RRG). The sources, methodological stages, and data of this study are explained in Section 4. Section 5 makes some semantic distinctions relevant for the terminology and scope of the present study by considering additional evidence from Present-Day English verbs of learning. Section 6 examines the predication from a semantic viewpoint and describes the linking semantics-syntax. Section 7 deals with the morpho-syntactic constructions and alternations found with verbs of learning. Finally, Section 8 summarizes the results of this study and draws the main conclusions.

\section{Review of previous research}

Most studies in the neighboring areas of Old English semantics and syntax concentrate on syntax (for instance, Visser 1963-1973, McLaughlin 1983, Mitchell 1985, Campbell 1987, Traugott 1992, Denison 1993, Quirk \& Wrenn 1994, Hogg \& Fulk 2011). Semantics has drawn less attention and has usually been considered in isolation from syntax (Weman 1933, Kastovsky 1992, Martín Arista 2018). With respect to the avenues of research just outlined, an exception is found in the studies on verbal classes. Among the studies more directly related to semantics, the major contributions analyze verbs of sensory perception (Penttilä 1956), movement (Weman 1933, Ogura 2002), knowledge (Ono 1989), thinking (Ogura 1986b), sentiment (Ogura 2013), taste (Ogura 2008), and impersonal verbs (Ogura 1986a, Möhlig-Falke 2012). Other studies of semantic import, but more geared towards syntax, deal with constructions with self (Ogura 1989), verbal complementation (Molencki 1991, Denison 1993), oblique 
case marking (Allen 1995), non-finite constructions (Timofeeva 2010), and periphrastic constructions (Ogura 2018).

Further advances have been made by scholars who delve into the semantic motivation of Old English syntax on an up-to-date theoretical basis. The internal aspect of Old English verbs in terms of the Aktionsart types of RRG (Van Valin \& LaPolla 1997) has been analyzed by Martín Arista (2000a, 2000b). Besides, the Lexematic Functional Approach has proposed a catalogue of lexical templates and mapping principles that relies on the method of lexical representation of RRG. The Lexematic Functional Approach has been applied to some Old English verbal classes; verbs of feeling (C. García Pacheco 2013) and verbs of existence (L. García Pacheco 2013), among others, have been discussed within this framework. With a view to reconsidering the structure of the verbal lexicon of Old English, some recent studies assess the consistency of verbal classes according to semantic and syntactic principles couched in terms of Aktionsart types, logical structures, constructions, and alternations. So far, this line includes inaction verbs (Ojanguren López 2019a, forthc.), verbs of prohibition (Ojanguren López 2019b), end verbs (Ojanguren López 2020), and rejoice verbs (Martín Arista 2020). The present study intends to follow in these tracks. It concentrates on verbs of learning because they have not been discussed in previous literature or they have been mentioned in passing (Visser 1963-1973, McLaughlin 1983, Mitchell 1985).

\section{Theoretical foundations}

The framework of verb classes and alternations developed by Levin (1993) and the functional approach of RRG (Foley \& Van Valin 1984; Van Valin \& LaPolla 1997; Van Valin 2005, 2014) constitute the theoretical basis of this article.

The semantic and syntactic characteristics of English verbs are stressed by Levin (1993) by remarking that "the behavior of a verb, particularly with respect to the expression and interpretation of its arguments, is to a large extent determined by its meaning. Thus, verb behavior can be used effectively to probe for linguistically relevant pertinent aspects of verb meaning" (Levin 1993: 1). Verbal class and alternations are the key concepts in this model since they "are manifested across languages by verbs of the same semantic types" (Levin 1993: 10). Regarding argument realization, the meaning components of a particular verb restrict their grammatical behavior or, put in another way, "verbs that fall 
into classes according to shared behavior would be expected to show shared meaning components" (Levin 1993: 5).

While the semantics motivates the syntax of a given verb within a certain class, morpho-syntactic alternations result, for instance, from diathesis variants (Levin 1993: 22). Alternations are classified according to the partaking morphosyntactic realizations. Consequently, distinctions are made between alternations depending on transitivity, arguments included in the verb phrase, oblique subjects, reflexivity, passivization, and other types of constructions. For example, give verbs (Levin 1993: 138), which include feed, give, lease, lend, loan, pass, pay, peddle, refund, render, rent, repay, sell, serve, and trade, participate in the dative alternation illustrated in (1):

(1) Dative Alternation (Levin 1993: 138)

They lent a bicycle to me.

They lent me a bicycle.

These verbs "display the dative alternation, though there may be some differences of opinion concerning whether some of these verbs actually are found in the double object construction", according to Levin (1993: 138). Hence, generalizations across different verb classes can be made on the basis of alternations.

Several issues may arise when this framework is applied to a former stage of the language because of the diachronic changes undergone by English throughout its evolution. Some of the most important aspects couched in terms of the argument realizations and alternations described by Levin (1993), including case marking, transitivization, prepositional government, and even lexical choice differentiate Old English from Present-Day English. In other words, it cannot be claimed that morpho-syntactic realizations and alternations have diachronic continuity. In fact, the radical changes to the form and structure of English in the past millennium point in the opposite direction. For this reason, the theoretical basis of the present study is comprised not only of the framework of verb classes and alternations, but also of an extensive theory of the association between semantics and syntax such as RRG. As Ojanguren López (2019a: 8) points out,

while an alternation describes a change to the realisation of the arguments of one or more verb classes, the Aktionsart classes of Role and Reference Grammar convey more general contrasts and, moreover, they account for contrasts that depend less on order and prepositional government than alternations. 
The aspects of the theory of RRG relevant for this discussion are reviewed in the remainder of this section.

Semantic representations are proposed in RRG that are based on the four Aktionsart classes distinguished by Vendler (1967): States, Achievements, Accomplishments, and Activities. The inventory of RRG Aktionsart types has been expanded to include Active Accomplishments and the causative version of all Aktionsart types (Van Valin \& LaPolla 1997) as well as Semelfactives (Van Valin 2005), both causative and non-causative. Aktionsart classes and their causative counterparts are shown in Table 1 .

Table 1. Examples of Aktionsart types in RRG (Van Valin 2005: 34)

$\begin{array}{ll}\text { a. State: } & \text { The boy is afraid. } \\ \text { a'. Causative state: } & \text { The dog frightens/scares the boy. } \\ \text { b. Achievement: } & \text { The balloon popped. } \\ \text { b'. Causative achievement: } & \text { The cat popped the balloon. } \\ \text { c. Semelfactive: } & \text { The pencil tapped on the table. } \\ \text { c' Causative semelfactive: } & \text { The teacher tapped the pencil on the table. } \\ \text { d. Accomplishment: } & \text { The ice melted. } \\ \text { d'. Causative accomplishment: } & \text { The hot water melted the ice. } \\ \text { e. Activity: } & \text { The soldiers marched in the park. } \\ \text { e'. Causative activity: } & \text { The sergeant marched the soldiers in the park. } \\ \text { f. Active accomplishment: } & \text { The soldiers marched to the park. } \\ \text { f. Causative active accomplishment: } & \text { The sergeant marched the soldiers to the park. }\end{array}$

The projection from clausal semantics onto clausal syntax is guaranteed by logical structures that determine the semantics-syntax and the syntax-semantics linking (Van Valin \& LaPolla 1997: 102). Stative (predicate') and non-stative $\left(\mathbf{d o}^{\prime}\right)$ variants are distinguished in logical structures, in which $x, y$, and $z$ represent variables of the verbal arguments. INGR(essive), SEM(e)L(factive), BECOME, and CAUSE are metalinguistic predicates that mark, respectively, ingressives, semelfactives, accomplishments, and causatives. The logical structure corresponding to each Aktionsart type can be seen in Table 2.

The semantic analysis of RRG revolves around the generalized semantic macroroles of Actor and Undergoer, which make grammatical generalizations across sets of thematic roles (Van Valin \& LaPolla 1997: 141). The Actor is the first argument of an agentive verb, while the Undergoer is the second argument of a transitive verb as well as the first argument of a stative verb. The relation 
Table 2. Lexical representations for Aktionsart classes (Van Valin 2005: 45)

\begin{tabular}{|c|c|}
\hline Aktionsart Class & Logical Structure \\
\hline STATE & predicate' $\left.^{\prime} \mathrm{x}\right)$ or $(\mathrm{x}, \mathrm{y})$ \\
\hline ACTIVITY & do $^{\prime}(\mathrm{x}$, [predicate $(\mathrm{x})$ or $\left.(\mathrm{x}, \mathrm{y})]\right)$ \\
\hline ACHIEVEMENT & $\begin{array}{l}\text { INGR predicate' }(x) \text { or }(x, y) \text {, } \\
\text { or INGR do' }\left(x,\left[\text { predicate }^{\prime}(x) \text { or }(x, y)\right]\right)\end{array}$ \\
\hline SEMELFACTIVE & $\begin{array}{l}\text { SEML predicate' }(\mathrm{x}) \text { or }(\mathrm{x}, \mathrm{y}) \\
\text { or SEML do' }(\mathrm{x}, \text { [predicate' }(\mathrm{x}) \text { or }(\mathrm{x}, \mathrm{y})])\end{array}$ \\
\hline ACCOMPLISHMENT & $\begin{array}{l}\text { BECOME predicate' }(\mathrm{x}) \text { or }(\mathrm{x}, \mathrm{y}) \text {, } \\
\text { or BECOME do' }(\mathrm{x},[\text { predicate' }(\mathrm{x}) \text { or }(\mathrm{x}, \mathrm{y})])\end{array}$ \\
\hline ACTIVE ACCOMPLISHEMNT & $\begin{array}{l}\left.\text { do' }^{\prime}(\mathrm{x}, \text { [predicate1' }(\mathrm{x},(\mathrm{y}))]\right) \\
\text { \& BECOME predicate2' }(\mathrm{z}, \mathrm{x}) \text { or }(\mathrm{y})\end{array}$ \\
\hline CAUSATIVE & $\begin{array}{l}\alpha \text { CAUSE } \beta \text {, where } \alpha, \beta \text { are logical structures of } \\
\text { any type }\end{array}$ \\
\hline
\end{tabular}

between argument position and macrorole is established in the ActorUndergoer Hierarchy, which specifies that the Actor will be the leftmost argument in the hierarchy whilst the Undergoer will be the rightmost one. The number of explicit macroroles that a predicate may take is determined by its macrorole transitivity (Van Valin \& LaPolla 1997: 150-151), which distinguishes three types: transitive ( 2 macroroles), intransitive (1 macrorole), and atransitive (0 macroroles).

In RRG, the grammatical concepts of subject and object are not regarded as universal. The concept of Privileged Syntactic Argument (PSA) is used instead. The first argument is PSA in active constructions, but the second argument becomes PSA in passive constructions. The PSA controls agreement with finite verbs. Any other clause involves either direct core arguments or oblique core arguments (marked by the oblique morphological cases genitive and dative or by prepositional government).

Linking, or the relation between semantics and syntax, is defined in both directions: from semantics to syntax (production) and from syntax to semantics (comprehension). This concept of linking ultimately guarantees that what is devised in the semantics is coded in the syntax of the clause. Crucial components of linking include verb agreement, case assignment, and prepositional government. Their interaction can be summarised as follows. In accusative languages such as English, the highest-ranking core macrorole is the controller of finite verb agreement. In terms of morphological case, in accusative languages 
such as English the argument receiving the highest-ranking core macrorole is case-marked nominative, while the other core macrorole argument selects the accusative case, and non-macrorole direct core arguments take the dative case (Van Valin \& LaPolla 1997: 325).

Finally, the projection of clausal semantics onto clausal syntax is described by means of the Layered Structure of the Clause (Van Valin \& LaPolla 1997: 26-29). The Layered Structure of the Clause is a hierarchical structure that consists of several semantic layers, which are necessary to suitably reflect the scope of operators (grammatical features including, among others, tense, aspect, and modality). The Layered Structure comprises the Clause, the Core (a verbal nucleus with its arguments and argument-adjuncts, as in Tom drank a glass of wine and They went to the cinema, respectively), and the Periphery, which is associated to the Core, as in The girls were dancing in the dark. One or more than one units of Clause level form the Sentence, as in Peter wanted to become a pilot and his family bought bim a belicopter.

\section{Sources, data, and steps of analysis}

This article has textual and lexicographical sources. On the one hand, the Dictionary of Old English Corpus (henceforward DOEC), the York-TorontoHelsinki Parsed Corpus of Old English Poetry and the York-Toronto-Helsinki Parsed Corpus of Old English Prose (hereafter, YCOE refers to both York corpora) are the textual sources. The DOEC has provided the textual excerpts and numbers whereas the parsing in the YCOE, when it was available for the fragment in question, has guided the morpho-syntactic analysis. On the other hand, both paper and electronic dictionaries, thesauri, and lexical databases constitute the lexicographical sources of the present study. The Old English dictionaries listed in the reference section have been checked, together with the Dictionary of Old English (hereafter DOE) for the verbs beginning with the letters A-I. The meanings and senses of the verbs at stake have been consulted in the Thesaurus of Old English and the Historical Thesaurus of the Oxford English Dictionary. Finally, the lexical and morphological data from the lexical database of Old English Nertbus, which contains approximately 32,000 entries, have been examined in order to make fine-grained distinctions of meaning.

The two steps adopted in the methodology of this work are the following. Firstly, a sub-corpus of Old English verbs of learning has been created. Secondly, the analysis of the linking semantics-syntax, constructions, and alternations 
presented by these verbs has been carried out. The second step also comprises the search of the texts for the attested inflectional forms of each verb.

The organization of lexical domains by Faber \& Mairal (1999), which takes internal aspect into account and considers notions such as negation and causativity, guides the creation of the sub-corpus. The lexical domain of verbs of learning is 'Cognition (to become aware through one's mind)', and the lexical subdomains include 'To come to know something' and 'To cause somebody to learn' (Faber \& Mairal 1999: 286). These subdomains are the starting point of the compilation of candidates for the verbal class of learning, which are then checked with the Thesaurus of Old English and the lexical database Nerthus. The initial twenty-six verbs have been reduced to fourteen after having rejected polysemic verbs that do not convey 'learn' as their primary meaning. The remaining ones present the primary meaning 'to become aware through one's mind', and belong to the lexical subdomains 'to come to know something' and 'to cause somebody to learn'.

The relevant DOE citations of the verbs beginning with the letters A-I have been searched in the DOEC. For their part, by drawing on the morphological paradigms found in Campbell (1987) and Hogg \& Fulk (2011), the canonical inflections of the verbs beginning with the letters $\mathrm{L}-\mathrm{Y}$ have been searched in the DOEC. This has raised the issue of the lack of textual occurrences of the canonical inflectional forms of some verbs in the DOEC. Eventually, it has been necessary to consult the lemmatized lists provided by Metola Rodríguez (2015), García Fernández (2018), and Tío Sáenz (2019), and to carry out some manual revision.

The resulting sub-corpus for this study is comprised of seven verbs, specifically (ge)cneordlēcan, gefrägian, (ge)fricgan, (ge)frignan, (ge)leornian, ofäcsian, and onfindan. All in all, 715 textual attestations (tokens) have been gathered and analyzed. The Appendix contains the inventory of verbs, as well as their inflectional forms and number of attestations.

The analysis in Section 6 and Section 7 relies on the DOEC, as shown in Figure 1; and the morphological classification and syntactic parsing of the YCOE, which is illustrated in Figure 2. Present-Day English translations draw on the references provided. 
[CP $004600(2.31 .3)]$

ðonne hi ðone godcundan wisdom leorniað.

'When they learn the divine wisdom.' (Sweet 1871: 30)

Figure 1. The arrangement of examples presented in the analysis

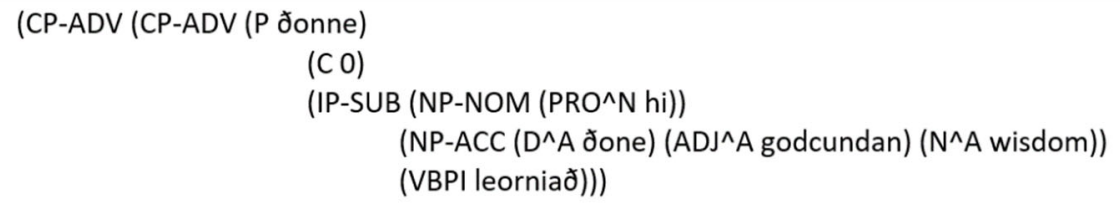

Figure 2. The syntactic description of an example in the $\mathrm{YCOE}^{2}$

\section{Further theoretical and terminological questions}

Some further theoretical and terminological questions arise when Present-Day English verbs of learning, for which much more evidence is available, are taken into account. These questions are addressed in this section.

Levin (1993: 144) proposes the class of learn verbs, which "describe the acquisition of information" and comprise acquire, cram, glean, learn, memorize, read, and study. According to Van Valin \& LaPolla (1997: 92), verbs of learning belong to the Aktionsart of Accomplishments.

These authors, therefore, do not make two semantic distinctions that are relevant for this study. Firstly, they do not draw any difference between durative and punctual verbs. Secondly, they do not distinguish clearly verbs of learning from verbs of teaching. These questions are discussed below, including the consequences for the analysis that is carried out in the following sections.

2 This article uses the following abbreviations for categories and features. Syntactic categories: CP-ADV (adverbial clause), NP (noun phrase); lexical categories: ADJ (adjective), ADV (adverb), D (determiner), N (noun), P (preposition), PRO (personal pronoun), VBPI (verb, present indicative); morphological case at word level: $\wedge \mathrm{A}$ (accusative), $\wedge^{\mathrm{N}}$ (nominative); morphological case at phrase level: -ACC (accusative), -NOM (nominative). 
The acquisition of knowledge is a durative change of state, whereas the acquisition of information often constitutes a punctual change of state. Two different verbal classes can be considered in this respect: verbs found in states of affairs that represent a learning process and imply knowledge acquisition, like learn, memorize, and study, and those which involve information acquisition without a prior learning process, such as realize, discover, find out, and get to know. The acquisition of knowledge conveys a durative process of change of state, which is accounted for in RRG by means of the Aktionsart type of the Accomplishment. The acquisition of information, on the other hand, is more suitably represented by means of the Aktionsart type of the Achievement. The logical structures, based on Van Valin \& LaPolla (1997: 105), and two illustrative examples can be seen in (2).

(2) a. Mary learned French.

BECOME know' (Mary, French)

b. Mary discovered the truth.

INGR discover' (Mary, the truth)

A further semantic distinction between learning and teaching verbs related to the first participant can be drawn. The causative version of verbs of learning selects the thematic role Effector for the first argument of the causing predication, thus reflecting the fact that the focus of the process is on the learner, as in Pythagoras learned masonry from the Egyptians; and, moreover, that the causer of the transfer of knowledge may not be human or volitive, as in $I$ realized from her paintings that blue was her favorite color. Verbs of teaching, which emphasize the role of the causer of the transfer of knowledge, can be decomposed as to cause someone to learn and, consequently, involve a prototypical Agent, as in The headmaster taught us Russian.

At this point, the analysis of Pythagoras learned masonry from the Egyptians as a Causative Accomplishment calls for an explanation. If the focus of the analysis is put on syntax, a constituent like from the Egyptians may be considered optional and, as such, should not be analyzed as a constituent of the verb. This is incompatible with the Causative Accomplishment Aktionsart, which requires a first argument coding the initiator of the learning process. On the other hand, if semantics is prioritized in the analysis, the participant the Egyptians constitutes the point of departure of the learning analysis and the participant the Egyptians can be analyzed as the first argument of the causing predication. In order to 
distinguish the logical structure from teaching verbs, the thematic role Effector is preferred over Agent, which is put aside for verbs of teaching. While the oblique marking of from the Egyptians is an argument against this analysis, the presence of nominalizations from verbal predications in the first position of the causing predication constitutes further evidence in favor of the Causative Accomplishment version. This is the case with predications like She learned oratory from the pastor's praying, which can be paraphrased as The pastor's praying caused her to learn oratory and, ultimately, rendered as The fact that the pastor prayed caused her to learn oratory. All factors considered, the causative analysis of oblique first arguments of causing predications like from ber paintings, from the Egyptians, or from the pastor's praying emphasizes the semantics of the phenomenon and is compatible with the general orientation of RRG.

Bearing these questions in mind, the analysis of Old English verbs puts aside teaching verbs and discusses the transfer of both knowledge and information, or, in other words, deals with the Achievement and Accomplishment variants of the verbs in question, including the non-causative and the causative versions.

\section{The linking semantics-syntax in Old English verbs of learning}

This section describes the Aktionsart types and logical structures of Old English verbs of learning. The particular characteristics of the linking semantics-syntax, explicitly the thematic roles, the semantic properties of the participants, semantic macroroles, and PSA are included as well.

Four types of Aktionsart, including Accomplishments, Achievements, and their correspondent causative versions, are presented by Old English verbs of learning. Accomplishments describe states of affairs in which an Experiencer, typically human, learns a Content, while in the states of affairs of Achievements the Experiencer becomes aware of a Content. Figure 3 represents the logical structure of Accomplishments and Achievements.

BECOME know' (x, y)

INGR discover' $(x, y)$

Figure 3. The logical structures of Accomplishments and Achievements with verbs of learning 
Most of the Old English verbs of learning examined show the logical structures of Accomplishments and Achievements in Figure 3, which are exemplified by (3a) and (3b).

(3) a. $\quad[$ Or $1022600(5.23 .27)]$

pa sade be Pompeius pat he par drycraftas geleornode.

'Pompeius then said that he there learned magic.' (Bately 1980: 267)

BECOME know' (he, drycreftas)

b. [Bede 5013900 (7.404.16)]

in Jam anum be geleornode monna cynne ingong geopenian Jes beofonlican lifes.

'Whereby alone he had learnt that entrance into the kingdom of heaven is opened to mankind.' (Miller 1959: 405)

INGR discover' (he, monna cynne ingong geopenian ðas heofonlican lifes)

On the other hand, in Causative Accomplishments a most frequently human initiator makes the Experiencer learn the Content, whereas in Causative Achievements the initiator causes the Experiencer to become aware of the Content. Figure 4 gives the logical structures of Causative Accomplishments and Causative Achievements.

[do' (x)] CAUSE [BECOME know' $(\mathrm{y}, \mathrm{z})]$

[do' (x)] CAUSE [INGR discover' $(\mathrm{y}, \mathrm{z})]$

Figure 4. The logical structures of Causative Accomplishments and Causative Achievements with verbs of learning

The logical structures of Causative Accomplishments and Causative Achievements in Figure 4 are illustrated by means of the fragments in (4a) and (4b) respectively.

(4) a. [HomS 40.3 (ScraggVerc 10) 003400 (89)]

Et me bie leornodon scondword \& lease bregdas.

'From me they learned blasphemous language and false deceits [or crafts].' (Nicholson 1991: 75)

[do' (me)] CAUSE [BECOME know' (bie, scondword \& lease bragdas)] 
b. [Bede 5035500 (14.442.6)]

pis spell ic leornade fram Pebthelme ðem arwyrðan biscope.

'I heard this story from the venerable bishop Pehthelm.' (Miller 1959: 443)

[do' (Pebthelme)] CAUSE [INGR discover' (ic, pis spell)]

The thematic role Cognizer is selected in Accomplishments and Achievements for the argument $x$ and for the argument $y$ in their causative versions. Cognizers experiment a state of cognition through which they learn the Content in Accomplishments or get to know it in Achievements, such as be 'he' in (3a) and (3b). The state of cognition may be externally motivated by an initiator that plays the thematic role Effector in Causative Accomplishments, like me 'me' in (4a), and in Causative Achievements, such as Pebthelme 'Pehthelm' in (4b). Finally, the thematic role Content is played by the second argument $(y)$ in Accomplishments, like drycreftas 'magic' in (3a), and in Achievements, such as monna cynne ingong geopenian yes beofonlican lifes 'entrance into the kingdom of heaven is opened to mankind' in (3b); and by the third argument $(z)$ in Causative Accomplishments, such as scondword \& lease bregdas 'blasphemous language and false deceits' in (4a), and in Causative Achievements, such as pis spell 'this story' in (4b).

Cognizers are human participants expresed by arguments that can be realized in the predication by personal pronouns (ic, $\partial u$, be, bēo, git, we, gèe, or bie)e, proper names (Elfred, Elfstan, Almachius, Arbatus, Basilius, Benedictus, Chrisantus, Daria, Gregorius, Ioseph, Iudith, Lucas, Rodbeard, Deodric, or Peotimus), or demonyms (Angle 'the Angles or English', Crēcas 'the Greeks', Gota 'Goth', or Romāne 'the Romans'). A remarkable number of instances of the thematic role Cognizer make reference to common nouns, such as bearn 'child', büend 'dweller, inhabitant', cild 'child', eardiend 'dweller, inhabitant', folc 'people, folk, nation', foldbüend 'man, earth-dweller', heleð 'man', mann 'person (male or female), man', ðēod 'people, nation', or wer 'man, male person'. Moreover, concrete nouns that refer to titles, occupations, or professions are also frequently used to express the Cognizer, including bisceop 'bishop', byrele 'cup-bearer', Cāsere 'Cæxar, emperor', cyning 'king, ruler, emperor', dōmere 'judge', eorl 'brave man, warrior', èbtere 'persecutor', fader 'father', gefèra 'companion', giest 'guest', bierde 'keeper, protector, guard', bläford 'ruler, master, lord', lēece 'doctor', landweard 'guard of a country', lārēow 'teacher, master, preacher', leorningcild 'student, scholar, pupil, disciple', prēost 'priest', ðēoden 'prince, king', ðegn 'thane', or wiga 'warrior', among others. On the other hand, non-human entities, e.g. émette 'ant', and 
abstract nouns, like cnibt 'youth' and laga 'law', are seldom expressed by the Cognizer.

In the same way as the Cognizer, the realizations of the Effector tend to make reference to human participants. These may be personal pronouns, proper names (Alexandre, Crisantus, Crīst, Gregorius, or Paulini), concrete nouns like bōcere 'learned man, scholar', fyrngewrit 'old writing or scripture', lärēow 'teacher, master, preacher', or $\bar{u} \partial w i t a$ 'scholar, sage', but also abstract nouns such as bodung 'message, preaching', gāst 'Holy Ghost', gebēere 'voice, cry', geoguð 'youth', (ge)segen 'saying, statement, conversation', (ge)smeeaung 'investigation', gesibt 'sight, vision', instruction', lārspell 'discourse, sermon', onwrigennes 'revelation', or scēad 'understanding, discernment'.

The thematic role Content distinguishes between information and knowledge acquisition, as described in Section 5. Thus, this thematic role is typically assigned to constituents that make reference to abstract nouns like $\bar{e}$ 'law', bebod 'command', bōc 'writing', creft 'art', dēed 'action, deed', èaðmōdnes 'humility', (ge)lēafa 'belief, faith', (ge)writ 'scripture', Grēcisc 'Greek', lār 'teaching', rēeling 'reading', sang 'song', spell 'story', ðēaw 'custom', ðing 'thing', or wissdōm 'wisdom, knowledge'.

The assignment of semantic macroroles with verbs of learning depends on the corresponding Aktionsart type. The Accomplishment and the Achievement present Macrorole transitivity 1, whereas the Macrorole transitivity of the Causative Accomplishment and the Causative Achievement is 2. The argument $x$ in the Accomplishment and the Achievement gets the macrorole Undergoer, while in the Causative Accomplishment and the Causative Achievement $x$ gets the Actor and the argument $y$ is the Undergoer. A non-macrorole core argument is also present in all four Aktionsart types that can receive the Undergoer macrorole when the Cognizer is not present in the state of affairs. This is illustrated by the Achievement in (5a), where ic 'I' is the Undergoer and beardran feobtan 'a more difficult contest' constitutes a non-macrorole core argument. On the other hand, in the Causative Achievement in (5b), pes wifes gebarum 'the woman's cries' receives the macrorole of Actor, pes cyninges pegnas 'the king's thanes' fulfils the Undergoer macrorole, and $p a$ unstilnesse 'the disturbance' is the non-macrorole core argument. 
(5) a. [Beo $015900(575)]$

No ic on nibt gefregn under beofones bwealf heardran feohtan.

'Never have I learned under the vault of heaven of a more difficult contest in the night.' (Hostetter 2015a)

INGR discover' (ic, heardran feobtan)

b. [ChronA (Bately) 025200 (755.13)]

\& pa on pas wifes gebarum onfundon pas cyninges pegnas pa unstilnesse.

'And then from the woman's cries the king's thanes became aware of the disturbance.' (Garmonsway 1975: 48)

[do' (pas wifes geberum)] CAUSE [INGR discover' (pas cyninges pegnas, pa unstilnesse)]

Figure 5 summarizes the most important characteristics of Old English verbs of learning with respect to Aktionsart type, the assignment of thematic role and macrorole, and the resulting logical structure.

BECOME know' $(\mathrm{x}, \mathrm{y})$ or INGR discover' $(\mathrm{x}, \mathrm{y})$ where:

$\mathrm{x}($ Cognizer $)=$ Undergoer; $\mathrm{y}$ (Content $)=$ non-macrorole core argument; Undergoer [do' (x)] CAUSE [BECOME know' (y, z)] or [do' (x)] CAUSE [INGR discover' (y, z)] where:

$\mathrm{x}($ Effector $)=$ Actor; $\mathrm{y}($ Cognizer $)=$ Undergoer; $\mathrm{z}$ (Content $)=$ non-macrorole core argument; Undergoer

Figure 5. Logical structures, thematic roles, and macrorole assignment

The assignment of PSA depends on Aktionsart type, argument realization, and passivization. With the Accomplishment and Achievement Aktionsart types, the PSA is assigned to the Undergoer, typically the Cognizer, as the tree diagram in (6) illustrates. However, when the Cognizer is not expressed in the state of affairs (passivization is often involved), the constituent that realizes the thematic role Content receives the macrorole Undergoer and subsequently gets PSA.

Causative Accomplishment and Causative Achievement types assign PSA to the Undergoer in the majority of the instances since the Effector is governed by a preposition, as shown in (7). Furthermore, when the Cognizer is not expressed in the state of affairs, the constituent that plays the thematic role Content gets the macrorole Undergoer and is assigned the PSA of the construction. If the Content is absent from the state of affairs, the PSA is assigned to the constituent that gets the macrorole Actor. 
(6)

[Or 1022600 (5.23.27)]

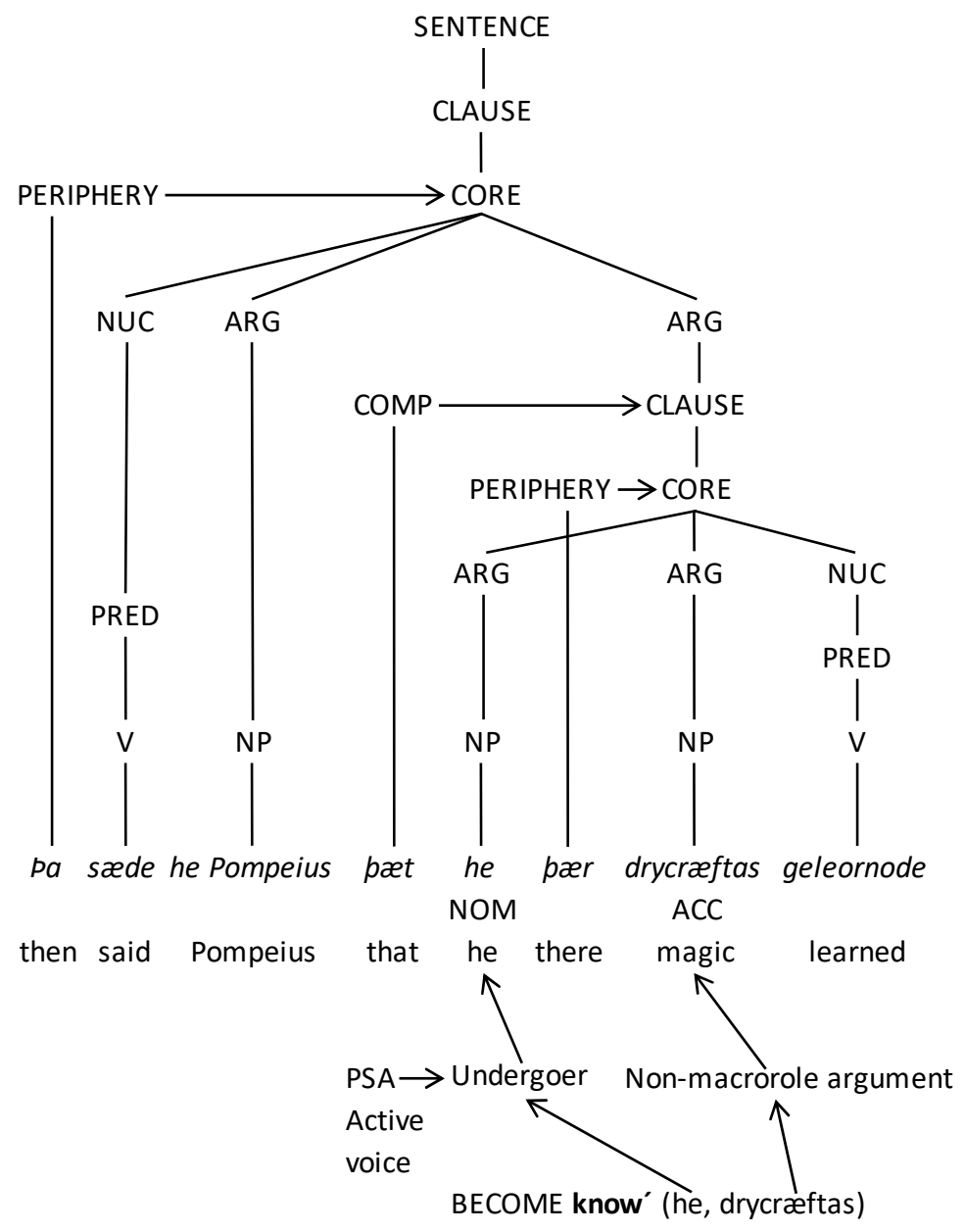


(7)

[Bede 5035500 (14.442.6)]

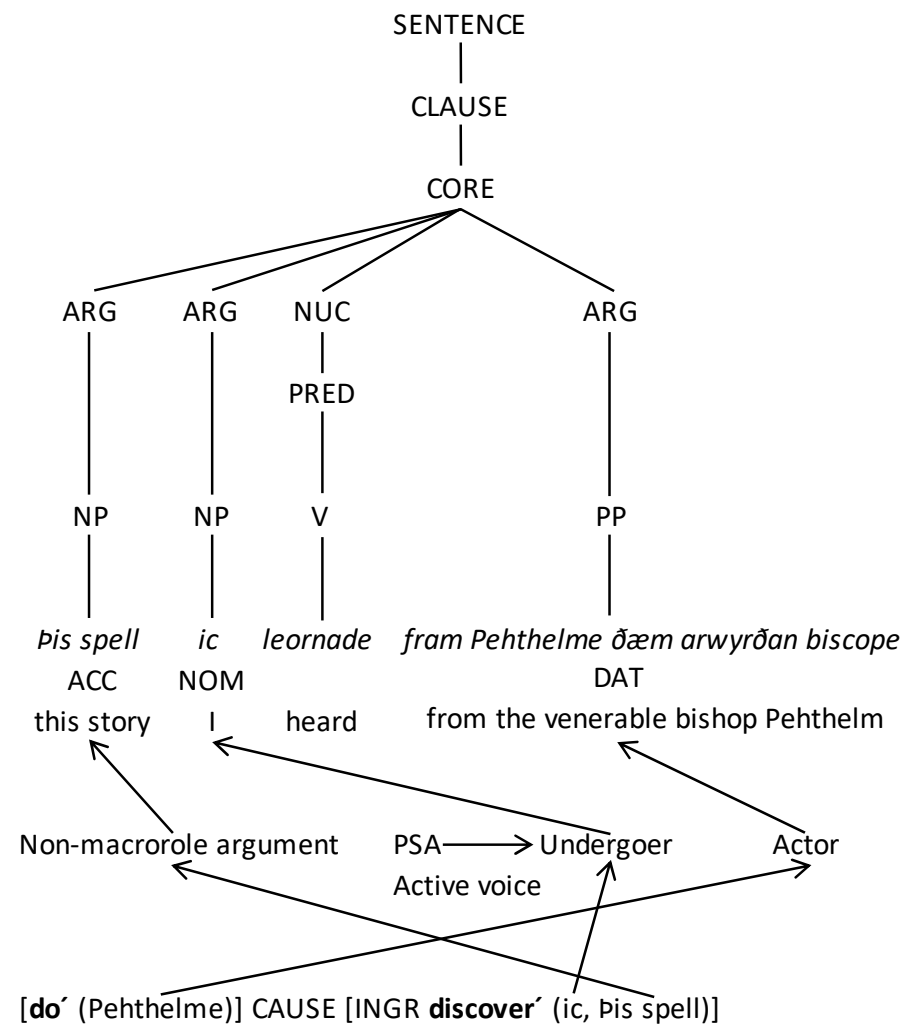

\section{Morphological case, constructions, and alternations}

This section goes through the morphological cases that the different participants in Old English verbs of learning take along with the different kinds of semantic-syntactic linking they present. Afterwards, the constructions and morpho-syntactic alternations found with these verbs, specifically the Causative Alternation, the Reflexive Alternation, the Effector Prepositional Government Alternation, and the Content Prepositional Government Alternation are considered. 
Cognizers involved in Accomplishments and Achievements present macrorole Undergoer, licensing nominative in the great majority of instances, as exemplified by (8). Still, they can take accusative and dative as well. The verbs (ge)cneordlēcan, gefrägian, (ge)fricgan, (ge)frignan, (ge)leornian, ofäcsian, and onfindan select the nominative case for the Cognizer; (ge)leornian takes the accusative case; and (ge)cneordlēcan and (ge)leornian receive a dative Cognizer.

(8) [Ch 1467 (Rob 91) 001000 (33)]

pa Elfstan abbod pis ofaxode pa com he to Eadsige arcebiscop. NOM

'When abbot Ælfstan was informed of this, he came to archbishop Eadsige.'

(Thorpe 1865: 340)

Effectors in Causative Accomplishments and Causative Achievements perform the macrorole of Actor and usually license the dative case, although the accusative case may also be selected. Both cases are prepositionally governed by $a t, b e$, from, mid, of, on, or purh. The dative case is taken by gefrägian, (ge)fricgan, (ge)frignan, (ge)leornian, ofäcsian, and onfindan, as in (9a); whereas only the Effectors of (ge)leornian and onfindan receive the accusative, as (9b) shows.

(9) a. [Or $3037200(11.82 .25)]$

pa wes seo sibb \& seo mildheortnes geendad pe bie at Alexandre geleornedon. DAT

'Then that peace and mercy which they had learned from Alexander, were ended.' (Bately 1980: 379)

b. [Bede $3060400(19.244 .8)]$

Forðon be purb gesybð geleornade, ge hwas he God bad \& to bim wilnade. ACC

'For by a vision he had learnt, both what he prayed God and desired.' (Miller 1959: 245)

Conversely, the Cognizers of Causative Accomplishments and Causative Achievements play the macrorole of Undergoer and are inflected for the nominative case exclusively when they are realized in the states of affairs. The verbs gefrägian, (ge)fricgan, (ge)frignan, (ge)leornian, ofäcsian, and onfindan opt for the nominative, as (10) illustrates. 
(10) [Æ LS (Chrysanthus) 002200 (75)]

pa cweð sum redbora pet Chrisantus leornode drycreft at pam Cristenum.

NOM

'Then said a certain counsellor, that Chrysanthus had learnt magic from the Christians.' (Skeat 1966b: 383)

Contents in the four Aktionsart types are non-macrorole core arguments although they can perform the Undergoer macrorole when Cognizers are not realized in the states of affairs. The accusative case is preferred, but Contents can also receive nominative, genitive, or dative; the accusative and the dative may be prepositionally governed. Additionally, clauses can also perform the thematic role Content, including direct and indirect questions, that-clauses, and infinitival clauses. The verbs (ge)fricgan, (ge)frignan, (ge)leornian, ofäcsian, and onfindan take the accusative case, as illustrated by (11a); the nominative is selected by (ge)fricgan, (ge)leornian, and onfindan; the genitive is licensed by (ge)fricgan, (ge)frignan, and (ge)leornian; whereas the verbs (ge)cneordlēcan, (ge)frignan, and (ge)leornian opt for the dative case; (ge)cneordlëcan, (ge)fricgan, (ge)leornian, ofācsian, and onfindan realize Content through a Clause (direct and indirect questions), as can be seen in (11b); the verbs (ge) cneordlēcan, (ge)fricgan, (ge)frignan, (ge)leornian, ofācsian, and onfindan present a clause as Content, as in (11c), which is also represented as a tree diagram in (12); finally, (ge)fricgan, (ge)frignan, (ge)leornian, and onfindan take a Content Core (infinitival clause), as shown in (11d).

(11) a. [Men $004400(189)]$

We pa apelingas fyrn gefrunan pat by foremare.

ACC

'Then we have learned about those noblemen of old.' (Hostetter 2015b)

b. [Æ LS (Mark) 004200 (147)]

ac he leornode swaðeah of Petres bodunge bu he ða boc gesette.

clause

'But he learned, nevertheless, from Peter's preaching, how he should write the book.' (Skeat 1966a: 331) 
c. [ÆCHom I, 5008200 (222.172)]

Đa gefran ioseph pat archelaus rixode on iudea lande after his feder berode. clause

'Then Joseph learned that Archelaus reigned in Judaea after Herod his father.' (Thorpe 1844: 89)

d. [And 033900 (1093)]

Đa ic lungre gefragn leode tosomne burgwaru bannan.

core

'Then, as I have heard, a gathering of the townsmen was proclaimed.'

(Root 1899: 35)

(12)

[AECHom I, 5008200 (222.172)]

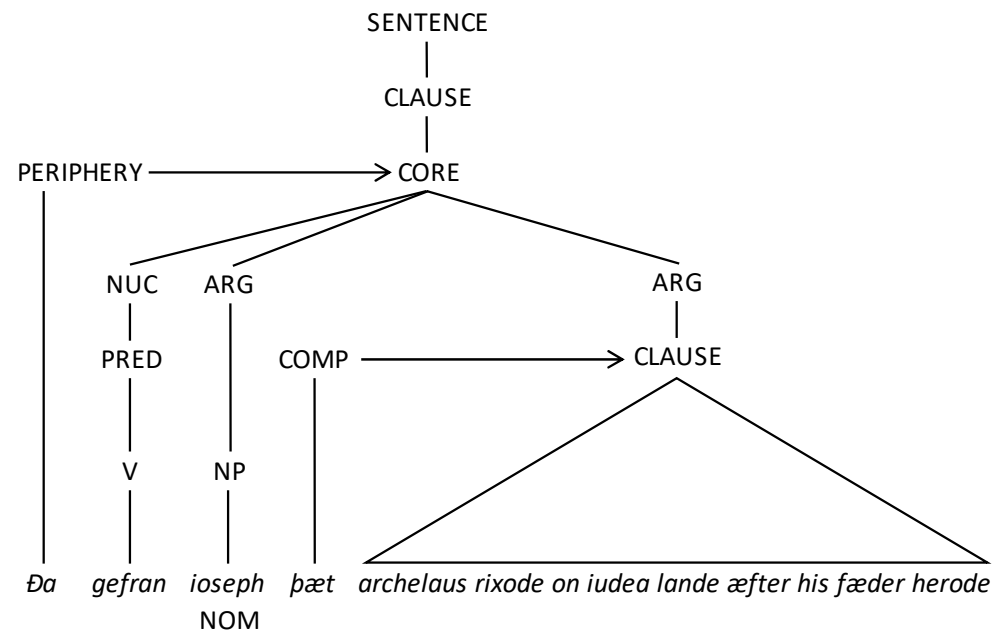

Then learned Joseph that Archelaus reigned in Judaea after Herod his father

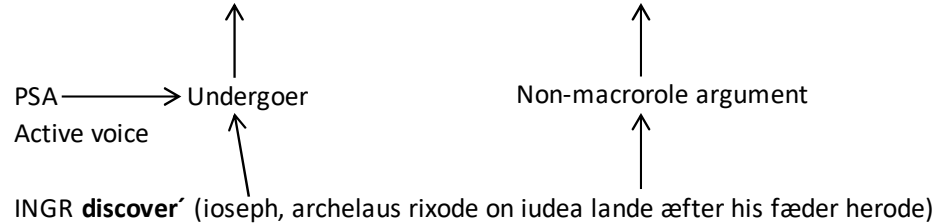

Table 3 below shows the linking of thematic role and morphological case and the corresponding distribution among Old English verbs of learning. 
Table 3. Linking with Old English verbs of learning

\begin{tabular}{|c|c|c|c|c|c|c|c|c|c|c|}
\hline \multicolumn{3}{|c|}{ 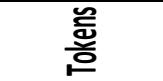 } & 의 & $\rightarrow$ & 9 & 요 & 名 & $\approx$ & 苯 & 늗 \\
\hline \multicolumn{3}{|c|}{ 要 } & - & $\rightarrow$ & 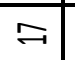 & 年 & $\exists$ & p & 夏 & $\nexists$ \\
\hline & $a$ & 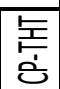 & & & $\rightarrow$ & & $m$ & & & $\sigma$ \\
\hline & $\theta$ & \begin{tabular}{|l|} 
容 \\
它
\end{tabular} & & & $\sigma$ & & $\sim$ & & & c \\
\hline 空 & 产 & \begin{tabular}{|l|} 
岁 \\
客
\end{tabular} & & & & & חـ & $\rightarrow$ & & $\omega$ \\
\hline પ્రు & 产 & प্口 & & & & & n & & $\neg$ & 0 \\
\hline & 高 & 密 & & & $\sim$ & $\nabla$ & $\sim$ & & & $\infty$ \\
\hline & 인 & 突 & $\rightarrow$ & & & $\sim$ & 0 & & & a \\
\hline & $\theta$ & 눈 & & & & $\rightarrow$ & $\infty$ & & $\sim$ & $\Rightarrow$ \\
\hline 言 & 产 & $\begin{array}{l}\text { 空 } \\
\text { 今 }\end{array}$ & & & & & 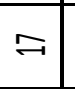 & $\sim$ & & 의 \\
\hline 票 & 立 & $\theta$ & & $\neg$ & & & 9 & & & 구 \\
\hline & $a$ & 을 & & & $\neg$ & & $r$ & & 9 & 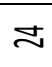 \\
\hline & 을 & \begin{tabular}{|l|} 
岁 \\
웡
\end{tabular} & $\rightarrow$ & & & $\rightarrow$ & $\approx$ & $\rightarrow$ & $\neg$ & 2 \\
\hline & 軎 & $\begin{array}{l}\text { 岂 } \\
\text { 至 } \\
\end{array}$ & & & $\sim$ & $\Rightarrow$ & $\Xi$ & & $\sim$ & $\mathscr{N}$ \\
\hline 言 & 立 & U্য & & & $\sim$ & $m$ & $\stackrel{\infty}{m}$ & $\rightarrow$ & in & go \\
\hline & 亯 & \begin{tabular}{|l|} 
高 \\
它
\end{tabular} & مـ & & $m$ & 0 & $\nabla$ & 0 & $\stackrel{2}{\sim}$ & 응 \\
\hline & 立 & 넌 & & & $\sim$ & $\Rightarrow$ & $\stackrel{\infty}{\sim}$ & $\Omega$ & $\approx$ & $\stackrel{8}{\sim}$ \\
\hline $\begin{array}{l}\text { 妾 } \\
\text { 总 } \\
\end{array}$ & 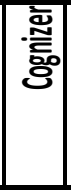 & 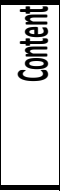 & 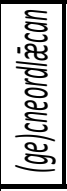 & 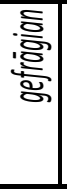 & 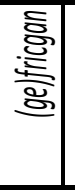 & 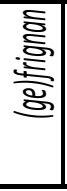 & 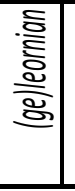 & $\begin{array}{l}\text {.5 } \\
\text { 응 }\end{array}$ & 흘 & 要 \\
\hline & 登 & & & & & & & & & \\
\hline
\end{tabular}


In Accomplishments and Achievements, (ge)cneordlēcan, (ge)fricgan, (ge)frignan, (ge)leornian, ofäcsian, and onfindan assign PSA to Undergoers depending on semantic macrorole and argument realization. Thus, the Cognizer be 'he' in (13a) receives PSA assignment as Undergoer, while the Content fif hella onlicnessa 'five images concerned with the horror of hell' in (13b) is assigned PSA as Undergoer, since the Cognizer has been omitted from the state of affairs.

(13) a. [ÆCHom II, 9001200 (73.24)]

He gecneordlabte after wisra lareowa gebysnungum.

'He was studious of the examples of wise teachers.' (Thorpe 1846: 119)

b. [HomU 15.1 (Scragg) 002500 (67)]

ponne syndon fif hella onlicnessa ber on worulde leornode on bocum.

'Wherefore, in books it is learned that in this world there are five images concerned with the horror of hell.' (Nicholson 1991: 67)

Similarly, the Undergoer of gefragian, (ge)fricgan, (ge)frignan, (ge)leornian, ofäcsian, and onfindan receives PSA in Causative Accomplishments and Causative Achievements, as Actors are normally governed by preposition. The Cognizer be 'he' in (14a) is assigned PSA and the Content pes 'this' in (14b) receives PSA assignment as a result of the lack of the Cognizer in the state of affairs.

(14) a. [ÆCHom II, 9008700 (79.220)]

for Jan ðe he ofaxode. at ðam lareowum his bale pat cristes ðeowdom ne sceal beon geneadad.

'For he had been informed by the teachers of his salvation, that Christ's service should not be forced.' (Thorpe 1846: 131)

b. $\quad$ [HomS 24 (ScraggVerc 1) 002700 (37)]

Frin pas pas pa men pe min word \& mine lare gehyrdon.

'Ask this of those men who heard my word and my lesson.' (Nicholson 1991: 19)

Turning to grammatical voice, (ge)fricgan, (ge)leornian, and onfindan take part in both options, but (ge)cneordlēcan, gefrägian, (ge)frignan, and ofäcsian show the active voice only. Voice diathesis with (ge)leornian is illustrated in (15). 
(15) a. [PPs $123200(118.125)]$

syle andgit, pat ic pine gewitnesse wel leornige.

'Grant me understanding, so that I may thoroughly learn your revelation.' (O’Neill 2016: 503)

b. [HomU 15.1 (Scragg) 001100 (34)]

Đonne syndon preo deapas leornode on bocum.

'There are three deaths learned about in the books.' (Nicholson 1991:

66)

Concerning constructions, the verbs which make the distinction between information and knowledge acquisition described in Section 5 and which include examples of both Aktionsart variants are (ge)cneordlēcan, (ge)fricgan, (ge)frignan, (ge)leornian, ofäcsian, and onfindan, as can be seen in (16) with respect to onfindan. For its part, gefrägian appears in one occurrence only, which depicts a Causative Achievement.

(16) a. [PPs $070200(93.8)]$

Onfindað pat and ongeotað pe on folce nu unwiseste ealra syndon.

'Let those who are the most foolish of all among the people learn and recognize now.' (O’Neill 2016: 369)

BECOME know' (pe on folce unwiseste ealra syndon, pat)

b. $\quad$ [Beo $063400(2300)]$

He pet sona onfand dat hefde gumena sum goldes gefandod, heabgestreona. 'He discovered at once that some human had tampered with the hightreasures, the gold.' (Hostetter 2015a)

INGR discover' (He, Jat hafde gumena sum goldes gefandod)

Table 4 presents the findings that have been previously discussed. 
Table 4. Old English verbs of learning: linking and constructions

\begin{tabular}{|c|c|c|c|c|c|c|c|c|}
\hline \multirow{2}{*}{. } & 愛 & & & $\times$ & & $x$ & & $x$ \\
\hline & 岁 & $\times 1$ & $\times$ & $\times$ & $\times$ & $x$ & $x$ & $x$ \\
\hline \multirow{12}{*}{ 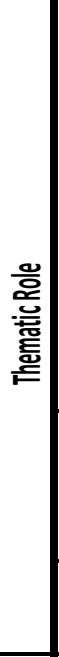 } & | & & & $x$ & $\times$ & $\times$ & & $x$ \\
\hline & 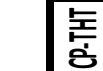 & $\times$ & & $\times$ & $\times$ & $x$ & $\times$ & $x$ \\
\hline & 豈 & $\times$ & & $\times$ & & $x$ & $\times$ & $x$ \\
\hline & $\sqrt[5]{5}$ & $x$ & & & $\times$ & $x$ & & \\
\hline & 惫 & & & $\times$ & $\times$ & $x$ & & \\
\hline & प्ष & & & $x$ & $x$ & $x$ & $x$ & $x$ \\
\hline & 흘 & & & $x$ & & $\times$ & & $x$ \\
\hline & 空 & $\times$ & & & & $x$ & & \\
\hline & 諰 & & & & & $\times$ & & \\
\hline & $\sqrt{5}$ & $\times$ & $\times$ & $x$ & $x$ & $x$ & $x$ & $>$ \\
\hline & 흔 & & $\times$ & $\times$ & $x$ & $\times$ & $\times$ & $x$ \\
\hline & 兽 & & & & & $x$ & & $x$ \\
\hline \multirow{5}{*}{ 謇 } & 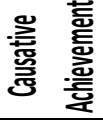 & & $\times$ & $\times$ & $x$ & $\times$ & $\times$ & $>$ \\
\hline & 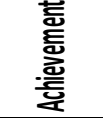 & $\times$ & & $x$ & $x$ & $\times$ & $x$ & $x$ \\
\hline & 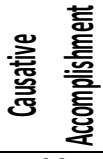 & & & $x$ & & $x$ & $\times$ & \\
\hline & 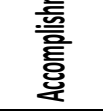 & $\times$ & & $x$ & $x$ & $\times$ & $x$ & $x$ \\
\hline & & 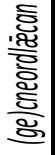 & 竞 & 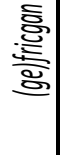 & 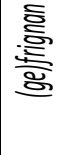 & 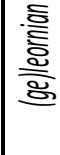 & 搃 & 妾 \\
\hline
\end{tabular}


Concerning alternations, (ge)fricgan, (ge)frignan, (ge)leornian, ofācsian, and onfindan take part in the Causative Alternation, as shown by ofäcsian in (17). On the other hand, (ge)cneordlēcan is only found in Accomplishments and Achievements, while gefrägian presents a Causative Achievement only.

(17) a. [ChronD (Cubbin) 071000 (1016.86)]

par he ofaxade pat se cyning was Eadmund.

'Where he had learned that king Eadmund was.' (Thorpe 1861: 124)

INGR discover' (be, pat se cyning was Eadmund)

b. [Æ LS (Martin) 000200 (1)]

and he wrat pa be him pa ðing pe he ofaxode, oððe at him sylfum, oððe at oprum mannum.

'And he therefore wrote concerning him the things which he had learned, either from himself or from other men.' (Skeat 1966b: 219) [do' (bim sylfum oððe oprum mannum)] CAUSE [BECOME know' (he, pa ðing)]

The Reflexive Alternation involves Causative Accomplishments and Causative Achievements in which Cognizers learn or get to know the Content from themselves. In other words, the Cognizer and the Effector are the same entity. The Effector takes a personal pronoun in either the accusative or the dative case and the particle self, as happens to (ge)leornian in (18b) compared with the non-reflexive alternation of the same verb represented in (18a). The verbs that partake in this alternation are (ge)leornian, ofäcsian, and onfindan.

(18) a. [Mart 5 (Kotzor) 065100 (Jy 7, B.4)]

ond at pare heo geleornode pat heo on clannesse god gelefde.

$$
\text { DAT NOM clause }
$$

'And from her she learned to believe in God with chastity.' (Herzfeld 1973: 115)

b. [Ch 1500 (Rob 3) 000400 (5)]

sua almeslice \& sua rebtlice sua be bim seolfa on bis wisdome geleornie. NOM DAT

'As charitably and as rightly as he of himself in his wisdom may learn.' (Thorpe 1865: 462)

The Effector in Active Acccomplishments and Causative Achievements can take the dative case alternating with the accusative or the dative governed by $a t, b e$, 
from, mid, of, on, or purh. This leads to the Effector Prepositional Government Alternation, which can be found with the verbs (ge)frignan and (ge)leornian, illustrated by means of the instances of (ge)leornian in (19).

(19) a. [Bede $4027500(14.296 .32)]$

pes monungum be gelered wes \& geleornade, pet he za beofonlecan

DAT NOM clause

eadignesse gebybte.

'By whose admonitions he had been taught and instructed to hope for heavenly bliss.' (Miller 1959: 297)

b. [ApT $018700(18.8)]$

Min dobtor girnð pet heo mote leornian at ðe ða gesaligan lare ðe $p u$

NOM DAT ACC

canst.

'My daughter desireth that she may learn from thee the happy lore that thou knowest.' (Thorpe 1834: 47)

Lastly, the Content Prepositional Government Alternation includes the alternation of Contents in Accomplishments and Achievements mostly in the accusative case but also in nominative, genitive, and dative with either accusative or dative governed by the prepositions be or of. The verbs (ge)cneordlēcan, (ge)frignan, and (ge)leornian participate in this alternation, which is illustrated with the examples of (ge)frignan in (20).

(20) a. [Dream $005000(75)]$

Hweðre me par drybtnes pegnas, freondas gefrunon.

ACC NOM

'Yet in that place the Lord's thegns, his friends, learned of me.'

(North et al. 2011: 289)

b. [Alex $027200(36.19)]$

lociað nu ealle up \& be swa bwylcum pingum swa ge willon frinan pence

$$
\text { DAT NOM }
$$

on bis heortan deagollice.

'Look up, all of you, and think secretly in your heart what you want to know.' (Orchard 1995: 249)

Table 5 summarizes the alternations examined in this section. 
Table 5. Alternations displayed by Old English verbs of learning

\begin{tabular}{l|c|c|c|c}
\hline & $\begin{array}{c}\text { The Causative } \\
\text { Alternation }\end{array}$ & $\begin{array}{c}\text { The Reflexive } \\
\text { Alternation }\end{array}$ & $\begin{array}{c}\text { The Effector } \\
\text { Prepositional } \\
\text { Government } \\
\text { Alternation }\end{array}$ & $\begin{array}{c}\text { The Content } \\
\text { Prepositional } \\
\text { Government } \\
\text { Alternation }\end{array}$ \\
\hline (ge) cneordlēcan & & & & $\mathrm{X}$ \\
\hline gefrāgian & & & & \\
\hline (ge)fricgan & $\mathrm{X}$ & $\mathrm{X}$ & $\mathrm{X}$ & $\mathrm{X}$ \\
\hline (ge)frignan & $\mathrm{X}$ & $\mathrm{X}$ & $\mathrm{X}$ & $\mathrm{X}$ \\
\hline (ge)leornian & $\mathrm{X}$ & $\mathrm{X}$ & & \\
\hline ofäcsian & $\mathrm{X}$ & $\mathrm{X}$ & & \\
\hline onfindan & $\mathrm{X}$ & $\mathrm{X}$ & \\
\hline
\end{tabular}

\section{Summary and conclusions}

All things considered, the answer to the research question raised in the present study is as follows. Firstly, the verbs (ge)frignan, (ge)leornian, ofäcsian, and onfindan are clearly members of the class since they participate in a considerable number of the constructions and alternations that define the class and present a significant number of textual occurrences. Secondly, the verb (ge)fricgan, in spite of its comparatively low number of textual occurrences, is considered a good candidate for class membership because it is found in all the constructions. This verb, on the other hand, is found in only one alternation. Finally, (ge) cneordlēcan and gefrägian are not members of the verbal class of learning. The verb (ge) cneordlēean shows both Accomplishment and Achievement variants and participates in the voice construction but is found in only one alternation and appears in a low number of textual occurrences. For its part, gefrägian is not found in any construction or alternation as it shows one textual occurrence only. The main conclusion of this study is that, if both meaning components and grammatical behavior are considered, the set of Old English verbs of learning cannot be considered a consistent verbal class.

On the theoretical side, the causative logical structure has been preferred over the association of a periphery to a core to represent information and knowledge acquisition. Although this solution is compatible with the priority given by RRG to semantics, it remains for future research to check this solution with other verbal classes. 


\section{References}

Dictionaries and thesauri

Bosworth, J. \& T. N. Toller 1973: An Anglo-Saxon Dictionary. Oxford, Oxford University Press.

Clark Hall, J. R. \& H. D. Meritt 1996: A Concise Anglo-Saxon Dictionary. Toronto, University of Toronto Press.

Healey, A. diPaolo ed. 2018: The Dictionary of Old English in Electronic Form A-I. Toronto, Dictionary of Old English Project, Centre for Medieval Studies, University of Toronto.

Kay, C., J. Roberts, M. Samuels \& I. Wotherspoon eds. 2009: Historical Thesaurus of the Oxford English Dictionary. 2 vols. Oxford, Oxford University Press.

Roberts, J. \& C. Kay with L. Grundy 2000 [1995]: A Thesaurus of Old English. 2 vols. Amsterdam, Rodopi.

Sweet, H. 1987: The Student's Dictionary of Anglo-Saxon. London, Macmillan.

Corpora and databases

Healey, A. diPaolo ed. with J. Price Wilkin \& X. Xiang 2004: The Dictionary of Old English Web Corpus. Toronto, Dictionary of Old English Project, Centre for Medieval Studies, University of Toronto.

Martín Arista, J. ed., L. García Fernández, M. Lacalle Palacios, A. E. Ojanguren López \& E. Ruiz Narbona 2016: NertbusV3. Online Lexical Database of Old English. Nerthus Project. Universidad de La Rioja. www.nerthusproiect.com

Pintzuk, S. \& L. Plug 2001: The York-Toronto-Helsinki Parsed Corpus of Old English Poetry. http://www-users.york.ac.uk//lang18/pcorpus.html

Taylor, A., A. Warner, S. Pintzuk \& F. Beths 2003: The York-Toronto-Helsinki Parsed Corpus of Old English Prose. https://www-users.york.ac.uk/_lang22/YcoeHome1.htm

Secondary Sources

Allen, C. 1995: Case Marking and Reanalysis: Grammatical Relations from Old to Early Modern English. Oxford, Clarendon Press.

Bately, J. 1980: The Old English Orosius (EETS s.s. 6). London, Oxford University Press.

Campbell, A. 1987: Old English Grammar. Oxford, Oxford University Press.

Denison, D. 1993: English Historical Syntax: Verbal Constructions. London, Longman.

Faber, P. \& R. Mairal 1999: Constructing a Lexicon of English Verbs. Berlin, Mouton.

Foley, W. \& R. Van Valin 1984: Functional Syntax and Universal Grammar. Cambridge, Cambridge University Press.

García Fernández, L. 2018: The Lemmatisation of the Verbal Lexicon of Old English on a Relational Database. Preterite-Present, Contracted, Anomalous and Strong VII Verbs. (Ph.D. dissertation.) La Rioja, Universidad de La Rioja. 
García Pacheco, C. L. 2013: Los Verbos de Sentimiento en Inglés Antiguo: Arquitectura Léxica e Interfaz Semántica-Gramática. (Ph.D. dissertation.) La Laguna, Universidad de La Laguna.

García Pacheco, L. M. 2013: El Dominio Verbal de la Existencia en Anglosajón. Análisis Semántico-Sintáctico. (Ph.D. dissertation.) La Laguna, Universidad de La Laguna.

Garmonsway, G. N. ed. and trans. 1975 [1972]: The Anglo-Saxon Chronicle. London, Dent \& Sons Ltd.

Herzfeld, G. 1973 [1900]: An Old English Martyrology (Early English Text Society, 116). London, Trübner.

Hogg, R. M. \& R. D. Fulk 2011: A Grammar of Old English. Vol. 2: Morphology. Oxford, Blackwell.

Hostetter, A. K. 2015a: Beowulf. Rutgers. https://oldenglishpoetry.camden.rutgers.edu/ beowulf/

Hostetter, A. K. 2015b: The Menologium. Rutgers. https://oldenglishpoetry. camden.rutgers.edu/the-menologium/

Kastovsky, D. 1992: Semantics and Vocabulary. In R. Hogg ed. The Cambridge History of the English Language. Vol. I: The Beginnings to 1066. Cambridge, Cambridge University Press: 290-408.

Levin, B. 1993: English Verb Classes and Alternations. Chicago, University of Chicago Press.

Martín Arista, J. 2000a: Sintaxis Medieval Inglesa I: Complementación, Caso y Sintaxis Verbal. In I. de la Cruz Cabanillas \& J. Martín Arista eds. Lingüística Histórica Inglesa. Barcelona, Ariel: 224-312.

Martín Arista, J. 2000b: Sintaxis Medieval Inglesa II: Funciones, Construcciones y Orden de Constituyentes. In I. de la Cruz Cabanillas \& J. Martín Arista eds. Lingüistica Histórica Inglesa. Barcelona, Ariel: 313-377.

Martín Arista, J. 2018: The Semantic Poles of Old English: Toward the 3D Representation of Complex Polysemy. Digital Scholarship in the Humanities 33.1: 96111.

Martín Arista, J. 2020: Old English Rejoice Verbs. Derivation, Grammatical Behaviour and Class Membership. POETICA 93: 133-153.

McLaughlin, J. 1983: Old English Syntax: A Handbook. Tübinge, Max Niemeyer Verlag. Metola Rodríguez, D. 2015: Lemmatisation of Old English Strong Verbs on a Lexical Database. (Ph.D. dissertation.) La Rioja, Universidad de La Rioja.

Miller, T. ed. and trans. 1959 [1891]: The Old English Version of Bede's Ecclesiastical History of the English People. Part I, 2. Oxford, Oxford University Press.

Mitchell, B. 1985: Old English Syntax. 2 vols. Oxford, Oxford University Press.

Möhlig-Falke, R. 2012: The Early English Impersonal Construction. An Analysis of Verbal and Constructional Meaning. Oxford, Oxford University Press.

Molencki, R. 1991: Complementation in Old English. Katowice, Uniwersytet Slaski. 
Nicholson, L. E. ed. 1991: The Vercelli Book Homilies. Translations from the Anglo-Saxon. London, University Press of America.

North, R., J. Allard \& P. Gillies eds. 2011: Longman Anthology of Old English, Old Icelandic and Anglo-Norman Literatures. London \& New York, Routledge.

Ogura, M. 1986a: Old English 'Impersonal' Verbs and Expressions. Copenhagen, Rosenkilde and Bagger.

Ogura, M. 1986b: Old English Verbs of Thinking. Neupbilologische Mitteilungen 87.3: 325-341.

Ogura, M. 1989: Verbs with the Reflexive Pronoun and Constructions with SELF in Old and Early Middle English. Cambridge, D. S. Brewer.

Ogura, M. 2002: Verbs of Motion in Medieval English. Cambridge, D. S. Brewer.

Ogura, M. 2008: Old English Verbs of Tasting with Accusative/Genitive/Of-Phrase. Neopbilologus 92.3: 517-522.

Ogura, M. 2013: Words and Expressions of Emotion in Medieval English. Frankfurt am Main, Peter Lang.

Ogura, M. 2018: Periphrases in Medieval English. Berlin, Peter Lang.

Ojanguren López, A. E. 2019a: The Classes of Old English Inaction Verbs. Linking, Alternations and Constructions. (Ph.D. dissertation.) La Rioja, Universidad de La Rioja.

Ojanguren López, A. E. 2019b: Old English Verbs of Prohibition. Grammatical Behaviour and Class Membership. SELIM 24.1: 1-28.

Ojanguren López, A. E. 2020: The Semantics and Syntax of Old English End Verbs. Atlantis 42.1: 163-188.

Ojanguren López, A. E. Forthcoming: Interclausal Relations with Old English Verbs of Inaction. Synchronic Variation and Diachronic Change. Revista Española de Lingüística Aplicada.

O’Neill, P. ed. 2016: Old English Psalms. Cambridge, Harvard University Press.

Ono, S. 1989: On Early English Syntax and Vocabulary. Tokyo, Nan'un-do.

Orchard, A. 1995 [1985]: Pride and Prodigies. Toronto, University of Toronto Press.

Penttilä, E. 1956: The Old English Verbs of Vision: A Semantic Study. Helsinki, Société Néophilologique.

Quirk, R. \& C. L. Wrenn 1994 [1955]: An Old English Grammar. DeKalb, Illinois, Northern Illinois University Press.

Root, R. K. trans. 1899: Andreas: The Legend of St. Andrew. New York, Henry Holt and Company.

Skeat, W. W. ed. 1966a [1881]: Elfric's Lives of Saints. Vol. I. Oxford, Oxford University Press.

Skeat, W. W. ed. 1966b [1890]: Elfric's Lives of Saints. Vol. II. Oxford, Oxford University Press.

Sweet, H. ed. 1871: King Alfred's West-Saxon Version of Gregory's Pastoral Care. London, Trübner \& Co. 
Thorpe, B. trans. 1834: The Anglo-Saxon Version of the Story of Apollonius of Tyre. London, John and Arthur Arch.

Thorpe, B. ed. and trans. 1844: The Homilies of the Anglo-Saxon Church. Vol. I. London, Red Lion Court.

Thorpe, B. ed. and trans. 1846: The Homilies of the Anglo-Saxon Church. Vol. II. London, Red Lion Court.

Thorpe, B. ed. and trans. 1861: The Anglo-Saxon Chronicle. Vol. II. London, Longman.

Thorpe, B. ed. and trans. 1865: Diplomatorium Anglicum Evi Saxonici. A Collection of English Charters. London, Macmillan \& Co.

Timofeeva, O. 2010: Non-finite Constructions in Old English. (Ph.D. dissertation.) Helsinki, University of Helsinki.

Tío Sáenz, M. 2019: The Lemmatisation of Old English Weak Verbs on a Relational Database. (Ph.D. dissertation.) La Rioja, Universidad de La Rioja.

Traugott, E. C. 1992: Syntax. In R. Hogg ed. The Cambridge History of the English Language. Vol. I: The Beginnings to 1066. Cambridge, Cambridge University Press: 168-289.

Van Valin, R. 2005: Exploring the Syntax-Semantics Interface. Cambridge, Cambridge University Press.

Van Valin, R. 2014: Some Questions Concerning Accomplishments. Lecture delivered at the 2014 Symposium on Verbs, Clauses and Constructions, held at Universidad de La Rioja.

Van Valin, R. \& R. LaPolla 1997: Syntax: Structure, Meaning and Function. Cambridge, Cambridge University Press.

Vendler, Z. 1967 [1957]: Linguistics in Philosophy. Ithaca, Cornell University Press.

Visser, F. 1963-1973: An Historical Syntax of the English Language. 4 vols. Leiden, Brill.

Weman, B. 1933: Old English Semantic Analysis and Theory: with Special Reference to Verbs Denoting Locomotion. Lund, A.-b. P. Lindstedts univ.-bokhandel. 


\section{Appendix. Verbal types and tokens}

The chosen verbs for this research are shown beneath, including the number of inflectional forms (tokens) of each of the verbs (types) between brackets.

(ge)cneordlēcan (16): cneorðlecendum (1), gecneordlecan (1), gecneordlecap (2), gecneordlace (4), gecneordlecen (1), gecneordlecende (1), gecneordlecon (1), gecneordlabte (1), gecnyrdlacað (1), gecnyrdlace (3).

gefrāgian (1): gefragade (1).

(ge)fricgan (19): frige (5), gefregen (7), gefregen (2), gefrigen (5).

(ge)frignan (50): fregnan (1), fregnanne (1), frin (3), frinan (1), gefragn (27), gefran (2), gefregn (1), gefrugnen (3), gefrugnon (1), gefrunan (2), gefrunen (3), gefrunon (5).

(ge)leornian (482): geleornad (5), geleornade (21), geleornað (3), geleornedon (5), geleornian (28), geleornianne (1), geleorniað (1), geleornie (1), geleornigan (1), geleornige (17), geleornigen (3), geleornion (1), geleornod (10), geleornode (44), geleornodest (1), geleornodon (20), geliorned (1), geliornod (3), geliornode (2), geliornodon (2), leornade (16), leornað (6), leornde (1), leornedon (9), leornedost (1), leornege (1), leornendum (1), leorneodes (1), leornien (2), leornian (57), leornianne (2), leorniað (36), leorniap (11), leornie (1), leornienne (5), leornigan (1), leornigað (2), leornige (41), leornigeað (1), leornigeap (1), leornigen (6), leornigeð (2), leornion (7), leornod (4), leornodan (3), leornode (58), leornodes (1), leornodest (6), leornodon (21), leornudan (1), liorna (2), liornode (2), liornodest (1), liornodon (2).

ofäcsian (33): ofacsian (1), ofabsade (1), ofabsian (1), ofabsode (1), ofaxade (1), ofaxian (11), ofaxie (2), ofaxod (2), ofaxode (12), ofaxxie (1).

onfindan (114): anfindan (1), anfunde (8), onfand (18), onfindað (2), onfindan (1), onfindap (1), onfinde (6), onfinder (3), onfinden (3), onfindende (3), onfindest (1), onfindep (1), onfond (4), onfunde (20), onfunden (20), onfundene (2), onfundon (20).

Author's address

Departamento de Filologías Modernas

Universidad de La Rioja

C/ San José de Calasanz, 33

26004 Logroño, La Rioja (España)

received: 10 February 2021

e-mail: miguel.lacalle@unirioja.es

revised version accepted: 9 March 2021 